\title{
Purification and Characterization of Extracellular Glucosyltransferase from Streptococcus mutans Serotype $b$ (Subspecies rattus)
}

\author{
By HIDEFUMI KUMADA, ${ }^{1}$ TOSHIO UMEMOTO ${ }^{1}$ MASAO ONISI, ${ }^{2}$ \\ HIDEAKI TSUMORI, ${ }^{3}$ ATSUNARI SHIMAMURA ${ }^{3}$ \\ AND HIDEHIKO MUKASA ${ }^{3 *}$ \\ ${ }^{1}$ Department of Oral Microbiology, Kanagawa Dental College, 82, Inaoka-cho, Yokosuka, \\ Kanagawa 238, Japan \\ ${ }^{2}$ Department of Oral Microbiology, School of Dentistry, Showa University, 1-5-8, Hatanodai, \\ Shinagawa, Tokyo 142, Japan \\ ${ }^{3}$ Department of Chemistry, National Defense Medical College, 2, Namiki 3-chome, Tokorozawa, \\ Saitama 359, Japan
}

(Received 30 October 1986; revised 13 January 1987)

\begin{abstract}
An extracellular glucosyltransferase (GT-S) synthesizing water-soluble glucan was purified from the culture supernatant of Streptococcus mutans BHT (serotype $b$, subsp. rattus) by DEAESepharose chromatography and preparative isoelectric focusing. The $M_{\mathrm{r}}$ of the enzyme was 155000 and the pI was 4.5. The GT-S had a specific activity of $10.2 \mathrm{i} . \mathrm{u}$. (mg protein) ${ }^{-1}$, an optimum pH of 6.0 and a $K_{\mathrm{m}}$ value of $0.8 \mathrm{~mm}$ for sucrose, and was activated twofold by dextran T10. The GT-S was immunologically partially identical with the corresponding enzymes in crude preparations from serotypes $c, e$ and $f$. The glucan synthesized de novo from sucrose by the GT-S was water-soluble and consisted of $29 \mathrm{~mol} \%$ of non-reducing terminal, $49 \mathrm{~mol} \%$ of $1,6-\alpha-$ linked, $11 \mathrm{~mol} \%$ of $1,3-\alpha$-linked and $11 \mathrm{~mol} \%$ of $1,3,6-\alpha$-branched glucose residues.
\end{abstract}

\section{INTRODUCTION}

Glycosyltransferases from Streptococcus mutans convert dietary sucrose into adhesive waterinsoluble polysaccharides which subsequently produce dental plaque (Gibbons \& Nygaard, 1968; Mukasa \& Slade, 1973). These polysaccharides are formed by cooperative action of watersoluble glucan-synthesizing glucosyltransferase (GT-S), insoluble glucan-synthesizing glucosyltransferase (GT-I), polysaccharide, and, in some $S$. mutans serotypes, fructosyltransferase (Carlsson, 1970; Mukasa \& Slade, 1974; Mukasa et al., 1979; Ciardi et al., 1977; Fukushima et al., 1981). Strains of $S$. mutans serotype $a$ (subsp. cricetus) and serotypes $d$ and $g$ (subsp. sobrinus) secrete three kinds of glucosyltransferase, while strains of serotype $b$ (subsp. rattus) and serotypes $c, e$ and $f$ (subsp. mutans) secrete glucosyl- and fructosyltransferases (Ciardi et al., 1976; Shimamura et al., 1983; Tsumori et al., 1983; Mukasa, 1986). The glucosyltransferases have been purified from serotypes $a$ to $g$ except for serotype $b$ (Mukasa et al., 1982a, 1985; Fukui et al., 1982; Shimamura et al., 1982, 1983; Koga et al., 1983; Kuramitsu \& Wondrack, 1983; Sato et al., 1984; Tsumori et al., 1985a, b). Glycosyltransferase complexes have been obtained from a serotype $b$ strain, which contained both glucosyl- and fructosyltransferase activities (Scales et al., 1975). It was essential, therefore, to purify and characterize the glucosyltransferases from a serotype $b$ strain to clarify the differences among glucosyltransferases from all the $S$. mutans serotypes. In this paper, we describe purification procedures for the

Abbreviations: GT-S, glucosyltransferase synthesizing water-soluble glucan; GT-SI, glucosyltransferase synthesizing highly branched 1,6- $\alpha$-glucan; GT-S2, glucosyltransferase synthesizing 1,6- $\alpha$-glucan with lesser amounts of $1,3-\alpha$-linked and 1,3,6- $\alpha$-branched glucose residues; GT-I, glucosyltransferase synthesizing waterinsoluble glucan (1,3- $\alpha$-glucan); IEF, isoelectric focusing; PAS, periodic acid-Schiff; PMSF, phenylmethanesulphonyl fluoride; APMSF, ( $p$-amidinophenyl)methanesulphonyl fluoride hydrochloride. 
GT-S from $S$. mutans BHT (serotype $b$, subsp. rattus), its physicochemical and kinetic characteristics, and the structure of the glucan synthesized by this enzyme from sucrose.

\section{METHODS}

Strains and culture conditions. Streptococcus mutans BHT (serotype $b$, subsp. rattus), originally isolated from human dental plaque by Zinner et al. (1965), was provided by Dr S. Hamada (Department of Dental Research, National Institute of Health, Shinagawa-ku, Tokyo, Japan). Cells were cultured in 5.31 chemically defined medium (Terleckyj et al., 1975) containing $0.05 \%$ Tween 80 at $37{ }^{\circ} \mathrm{C}$ for $10 \mathrm{~h}$. The $\mathrm{OD}_{550}$ of the culture was 4.5 and the $\mathrm{pH}$ was 4.7 . The culture supernatant obtained by centrifugation at $5500 \mathrm{~g}$ at $5{ }^{\circ} \mathrm{C}$ was made $0.1 \mathrm{~mm}$ and $0.01 \%$ with respect to PMSF and Merthiolate, respectively.

Purification of glucosyltransferase. (1) Ethanol fractionation. The culture supernatant (5.3 l) was treated with $50 \%(\mathrm{v} / \mathrm{v})$ ethanol below $0{ }^{\circ} \mathrm{C}$. The precipitate collected by centrifugation at $5500 \mathrm{~g}$ for $30 \mathrm{~min}$ was dissolved in $52 \mathrm{ml}$ distilled water and then used as the crude enzyme preparation.

(2) DEAE-Sepharose chromatography. The ethanol fraction $(52 \mathrm{ml})$ obtained above was mixed with $270 \mathrm{ml}$ $10 \mathrm{~mm}$-sodium maleate buffer, $\mathrm{pH}$ 6.0, containing $1 \mu \mathrm{M}$-APMSF, $0.1 \mathrm{mM}$-PMSF and $0.1 \mu \mathrm{g} \alpha_{2}$-macroglobulin $\mathrm{ml}^{-1}$, and then applied to a DEAE-Sepharose (Pharmacia) column $(1.8 \times 11 \mathrm{~cm})$ previously equilibrated with the same buffer containing $50 \mathrm{mM}-\mathrm{NaCl}$. The column was washed with $10 \mathrm{mM}$-sodium maleate buffer containing $50 \mathrm{~mm}-\mathrm{NaCl}$ and the enzyme was eluted with a linear gradient of 50 to $300 \mathrm{~mm}-\mathrm{NaCl}$ in this buffer (1 litre) at room temperature (approximately $20^{\circ} \mathrm{C}$ ). The column flow rate was $73 \mathrm{ml} \mathrm{h}^{-1}$ and fraction volumes of $5 \mathrm{ml}$ per tube were collected. The active fractions (nos 145-165) were combined and concentrated by adsorption to a DEAESepharose column $(1 \times 3 \mathrm{~cm})$ equilibrated with $10 \mathrm{~mm}$-sodium maleate buffer, $\mathrm{pH} 6 \cdot 0$, containing $150 \mathrm{~mm}-\mathrm{NaCl}$, $0.1 \mathrm{mM}-\mathrm{PMSF}, 1 \mu \mathrm{M}$-APMSF and $0.1 \mu \mathrm{g} \alpha_{2}$-macroglobulin $\mathrm{ml}^{-1}$ and by elution with $350 \mathrm{mM}-\mathrm{NaCl}$ in the same buffer. The concentrated enzyme solution was dialysed against $5 \mathrm{mM}$-sodium maleate buffer, $\mathrm{pH} 6 \cdot 0$, containing $1 \mu \mathrm{M}$-APMSF at $0^{\circ} \mathrm{C}$.

(3) Preparative IEF. The dialysed enzyme solution $(4.1 \mathrm{ml})$ was subjected to preparative IEF. The density gradient was formed manually (Vesterberg, 1971) with glycerol. Ampholine pH 4-6, Ampholine pH 3.5-10 and Triton X-100 were used at concentrations of $0.95,0.05$ and $0.1 \%$, respectively. The focusing was carried out at a constant wattage of $4 \mathrm{~W}$ for $3 \mathrm{~h}$ and then $8 \mathrm{~W}$ for $15.3 \mathrm{~h}$ at approximately $0{ }^{\circ} \mathrm{C}$. The active fractions (nos 57-65) were pooled and stored at $-40^{\circ} \mathrm{C}$.

Enzyme assay. The enzyme activity was measured as previously reported (Mukasa et al., 1979) in $1 \mathrm{ml} 0.1 \mathrm{M}$ sodium phosphate buffer ( $\mathrm{pH} \mathrm{6.5)} \mathrm{or} 0.1 \mathrm{M}$-sodium maleate buffer ( $\mathrm{pH} \mathrm{6.0)}$ containing $41.8 \mathrm{mM}$-sucrose and $0.01 \%$ Merthiolate with or without $0.34 \mathrm{mg}$ dextran T10. The reaction was linear for at least $12 \mathrm{~h}$ under these assay conditions.

The reducing sugar released from sucrose was measured by the method of Somogyi (1945), using fructose as a standard. One unit (i.u.) of total glycosyltransferase activity is defined as the amount of enzyme that releases $1 \mu \mathrm{mol}$ reducing sugar from sucrose $\min ^{-1}$ at $37^{\circ} \mathrm{C}$.

Polysaccharides were collected, washed as described by Mukasa et al. (1979) and measured by the phenol/sulphuric acid method (Dubois et al., 1956), using glucose as a standard. Fructan was measured by the method of Van Handel (1967) with some modifications as follows: $0.2 \mathrm{~g}$ anthrone was dissolved in a mixture of $95 \mathrm{ml}$ concentrated sulphuric acid (18 M) and $5 \mathrm{ml}$ distilled water, and subsequently added with $20 \mathrm{ml}$ distilled water at $4^{\circ} \mathrm{C}$. A sample solution, adjusted to $0.5 \mathrm{ml}$ with distilled water, and $3 \mathrm{ml}$ of the anthrone reagent were mixed at $4{ }^{\circ} \mathrm{C}$, and kept at $45^{\circ} \mathrm{C}$ for $20 \mathrm{~min}$. After the mixture had been cooled to room temperature, the $\mathrm{OD}_{620}$ was measured, using fructose as a standard. The amount of fructan was subtracted from the total amount of polysaccharides to give the amount of glucan. One unit (i.u.) of GT-S activity was the amount of enzyme catalysing the incorporation of $1 \mu \mathrm{mol}$ glucose from sucrose into glucan $\mathrm{min}^{-1}$.

The effect of dextran T10 on glucosyltransferase activity was tested with $0-0.5 \mathrm{mg}$ dextran $\mathrm{ml}^{-1}$ in $0.1 \mathrm{M}$-sodium maleate buffer ( $\mathrm{pH} 6.0$ ) containing $41.8 \mathrm{mM}$-sucrose.

Analytical IEF. This was done by the method of Mukasa et al. $(1982 b)$ in the presence of $0.1 \%$ Triton X-100 by using the low pI calibration kit (Pharmacia) as $\mathrm{pI}$ marker proteins. After focusing, protein was stained with Coomassie brilliant blue R-250. GT-S activity and reducing-sugar-release activity were directly detected in the gel as previously described (Mukasa et al., 1982b).

SDS-PAGE. This was done by the method of Weber \& Osborn (1969) in a $5 \%(\mathrm{w} / \mathrm{v})$ gel for $5.5 \mathrm{~h}$ at $5 \mathrm{~mA}$ per gel. Protein was stained with Coomassie brilliant blue R-250 and $M_{\mathrm{r}}$ was determined, using Bio-Rad high $M_{\mathrm{r}}$ protein standards. The enzyme activity in the gel was detected as previously reported (Russell, 1979b; Mukasa et al., $1982 b$ ).

Immunological procedure. The crude enzyme preparations from serotypes $a$ to $g$ were obtained by ethanol fractionation as described by Mukasa et al. (1985). Antisera against the crude and purified glucosyltransferases were prepared from male New Zealand White rabbits as previously described (Mukasa \& Slade, 1973). A double immunodiffusion test was done by the Ouchterlony technique (Ouchterlony, 1958) using $0.5 \%$ agarose gel. 
Determination of optimum $\mathrm{pH}$ and $K_{m}$ value. The optimum $\mathrm{pH}$ was estimated by the method of Tsumori et al. $(1985 a)$. The $K_{\mathrm{m}}$ value for sucrose was estimated by measuring the activity in $0.1 \mathrm{M}$-sodium maleate buffer (pH 6.0) containing 0.5-50 mM-sucrose by the direct linear plot method (Eisenthal \& Cornish-Bowden, 1974). The values quoted represent the mean of values from triplicate experiments.

Linkage analysis of glucan. The water-soluble glucan was synthesized by the purified enzyme $(14 \mu \mathrm{g})$ in $3.2 \mathrm{ml}$ $0.1 \mathrm{M}$-sodium maleate buffer (pH 6.0) containing $5 \%(\mathrm{w} / \mathrm{v})$ sucrose and $0.01 \%$ Merthiolate at $37^{\circ} \mathrm{C}$ for $8 \mathrm{~h}$. The synthesized glucan was washed (Mukasa et al., 1979), dialysed against distilled water and lyophilized. The glucan $(2.5 \mathrm{mg})$ was permethylated by the method of Hakomori (1964), hydrolysed, reduced with sodium borohydride, and acetylated. The resultant partially methylated alditol acetates were analysed by GLC (Shimamura et al., 1982).

Protein assay. Protein was determined by the Lowry method using bovine serum albumin as a standard. The protein content of the purified enzyme was also estimated by staining the gel after analytical IEF with Coomassie brilliant blue R-250 and by scanning with a densitometer (Chromatoscanner CS-910, Shimadzu) using bovine serum albumin as a standard.

Materials. DEAE-Sepharose CL-6B and dextran T10 were purchased from Pharmacia, PMSF from Calbiochem-Behring, APMSF from Wako Pure Chemicals, and Ampholines from LKB. All other chemicals were of analytical grade.

\section{RESULTS}

\section{Purification of GT-S}

The GT-S from $S$. mutans BHT, serotype $b$, which synthesized water-soluble glucan from sucrose, was purified 16 -fold with a $23 \%$ recovery as summarized in Table 1 . The GT-S fraction eluted from the DEAE-Sepharose column was contaminated by trace amounts of a minor GT-S species and fructosyltransferase (Figs 1 and 2). Further purification of the GT-S by preparative IEF gave a single active peak. This preparation synthesized more than $99.7 \%(w / w)$ of glucan from sucrose. Dextranase and inulinase activities were not detected in the preparation, as measured by using dextran T10 and inulin as substrates.

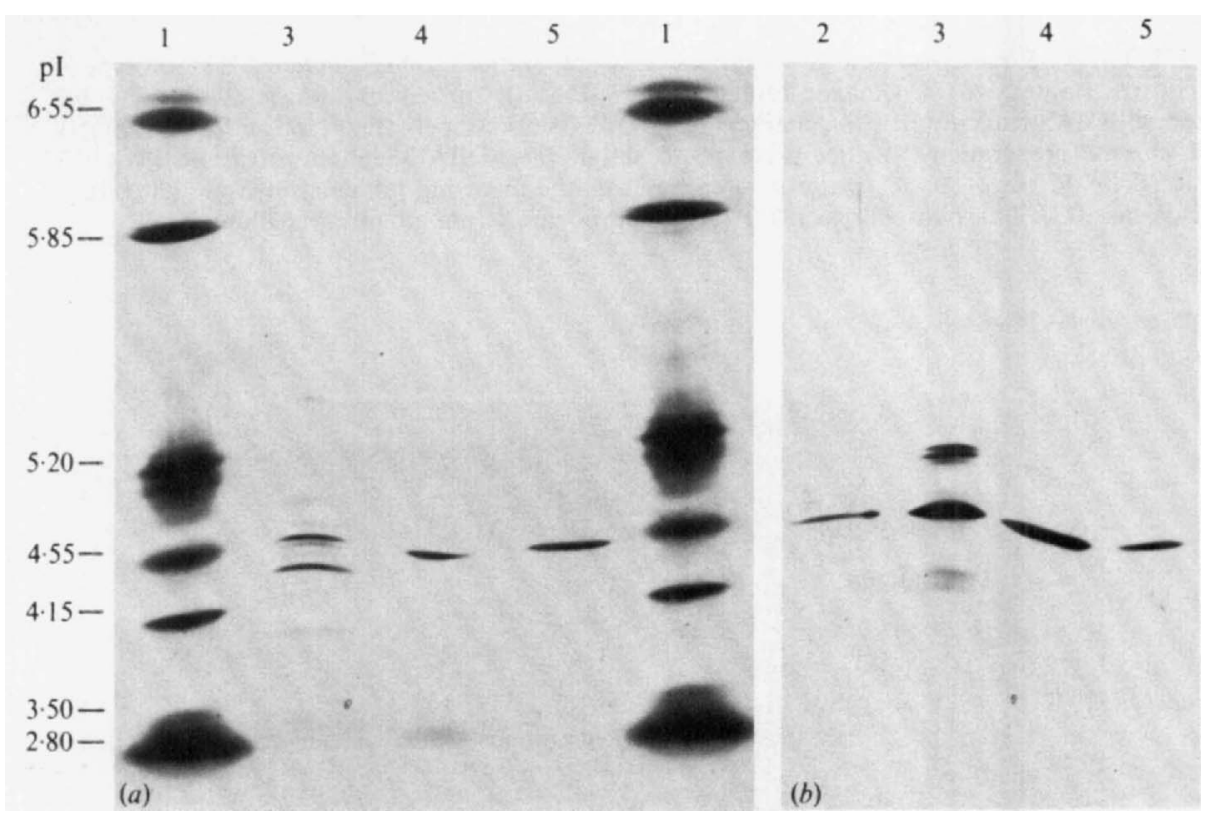

Fig. 1. IEF patterns of the glycosyltransferase preparations from $S$. mutans BHT (serotype $b$ ). Protein was stained with Coomassie brilliant blue R-250 $(a)$ and the polysaccharides synthesized by the glycosyltransferases were stained with PAS reagent $(b)$. Lanes: 1 , pI marker proteins $(10 \mu g) ; 2$, culture supernatant $(80 \mu \mathrm{g}$ for activity); 3, crude enzyme preparation $(4 \mu \mathrm{g}$ for protein, $2.3 \mu \mathrm{g}$ for activity); 4 , DEAE-Sepharose fraction $(0.9 \mu \mathrm{g}, 0.2 \mu \mathrm{g}) ; 5$, purified GT-S $(0.2 \mu \mathrm{g}, 0.02 \mu \mathrm{g})$. The pI values were determined by reference to the following pl markers: human carbonic anhydrase $B(6.55)$; bovine carbonic anhydrase B (5.85); $\beta$-lactoglobulin A (5.20); soybean trypsin inhibitor (4.55); glucose oxidase $(4 \cdot 15)$; amyloglucosidase $(3 \cdot 50)$; and pepsinogen $(2 \cdot 80)$. 

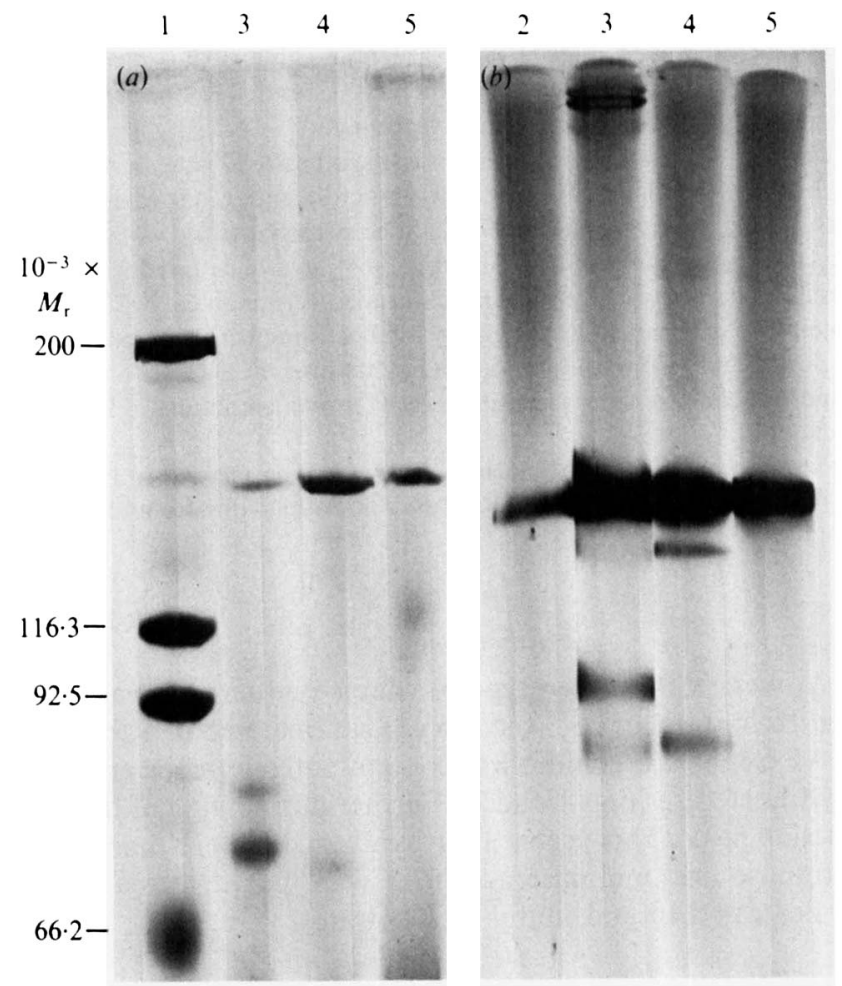

Fig. 2. SDS-PAGE patterns of the glycosyltransferase preparations from $S$. mutans BHT (serotype $b$ ). Protein was stained with Coomassie brilliant blue R-250 (a), and glycosyltransferase activity was stained with PAS reagent $(b) .1, M_{\mathrm{r}}$ markers $(2.5 \mu \mathrm{g}) ; 2$, culture supernatant (160 $\mu \mathrm{g}$ for activity); 3 , crude enzyme preparation ( $8 \mu \mathrm{g}$ for protein and activity); 4 , DEAE-Sepharose fraction $(3 \mu \mathrm{g}) ; 5$, purified GT-S $(0.7 \mu \mathrm{g})$. The $M_{\mathrm{r}}$ was estimated by using the following proteins: myosin (200000), $\beta$ galactosidase (116300), phosphorylase $b$ (92500), and bovine serum albumin (66200).
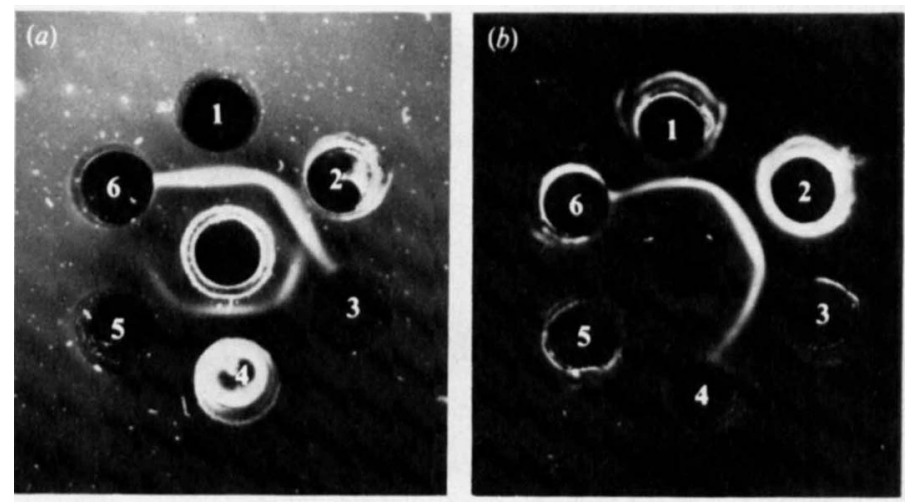

Fig. 3. (a) Immunodiffusion of the various glucosyltransferase preparations against anti-GT-S(b) serum (centre well; $15 \mu \mathrm{l})$. 1, Purified GT-S $(b)(1 \mu \mathrm{g}) ; 2-6$, crude enzyme preparation from strains: BHT $(b)$, Ingbritt $(c), \operatorname{LM} 7(e), \mathrm{OMZ} 175(f)$ and HS6 (a), respectively (30-100 $\mathrm{g}$ protein). (b) Immunodiffusion of the purified GT-S(b) (centre well; $1 \mu \mathrm{g}$ ) to various antisera $(15 \mu \mathrm{l}$ each). 1 , Anti-GT-S $(b) ; 2$, anticrude enzyme $(c) ; 3$, anti-GT-S $(c) ; 4$, anti-GT-I $(c) ; 5$, anti-GT-S1 $(a) ; 6$, anti-GT-S2 $(a)$. 
Glucosyltransferase of $S$. mutans serotype $b$

Table 1. Purification of GT-S from S. mutans BHT (serotype b, subsp. rattus)

\begin{tabular}{|c|c|c|c|c|c|}
\hline Step & $\begin{array}{l}\text { Total protein } \\
(\mathrm{mg})\end{array}$ & $\begin{array}{l}\text { Activity* } \\
\text { (i.u.) }\end{array}$ & $\begin{array}{l}\text { Specific activity } \\
\text { (i.u. } \mathrm{mg}^{-1} \text { ) }\end{array}$ & $\begin{array}{c}\text { Recovery } \\
(\%)\end{array}$ & $\begin{array}{c}\text { Purification } \\
\text { (-fold) }\end{array}$ \\
\hline Ethanol fractionation & $40 \cdot 0$ & $25 \cdot 1$ & 0.63 & 100 & 1 \\
\hline DEAE-Sepharose & $1 \cdot 2$ & $6 \cdot 3$ & $5 \cdot 3$ & $25 \cdot 1$ & $8 \cdot 4$ \\
\hline Preparative IEF & 0.56 & $5 \cdot 7$ & $10 \cdot 2$ & 22.7 & $16 \cdot 2$ \\
\hline
\end{tabular}

\section{Properties of GT-S}

Electrophoretic properties. The final GT-S preparation (preparative IEF preparation) consisted of a main GT-S species with a negligible amount of other GT-S species as found by analytical IEF (Fig. 1). Minor amounts of Coomassie-brilliant-blue-staining materials were apparent on SDS-PAGE gels (Fig. 2); these materials may have been derived from the Ampholine mixture used, since the broad bands disappeared when the gel was dialysed before staining (data not shown). The $M_{\mathrm{r}}$ of the major GT-S was $155000 \pm 2000$ (mean \pm SD of five experiments) by SDS-PAGE and the pI was 4.5 (mean of three experiments) (Figs 1 and 2). The GT-S activity stained with PAS coincided in position with reducing-sugar-release activity stained with 2,3,5-triphenyltetrazolium chloride (data not shown).

Immunological analysis. The purified GT-S and crude enzyme from strain BHT (serotype $b$ ) formed a single precipitin band with an anti-GT-S $(b)$ serum (Fig. $3 a$ ). Crude enzymes from strains Ingbritt $(c), \operatorname{LM} 7(e)$ and $\mathrm{OMZ} 175(f)$ also formed a single precipitin band with the antiGT-S $(b)$ serum, but these enzymes were partially identical with the GT-S $(b)$. Crude enzymes from HS6 $(a)$ (Fig. $3 a$ ), B13 $(d)$ and $6715(g)$ (not shown) did not react with the anti-GT-S $(b)$ serum. The purified GT-S $(b)$ also reacted with an anti-GT-S $(c)$ serum, but did not react with anti-GT-I $(c)$, anti-GT-S1 $(a)$, anti-GT-S2 $(a)$ (Fig. $3 b)$ and anti-GT-I $(a)$ sera (not shown).

Kinetic study. The optimum $\mathrm{pH}$ was 6.0 and the $K_{\mathrm{m}}$ value for sucrose was $0.8 \pm 0.2 \mathrm{~mm}$ (mean $\pm \mathrm{SD}$ ) at $\mathrm{pH} 6.0$. The enzyme activity was stimulated twofold by dextran $\mathrm{T} 10$ $\left(0.5 \mathrm{mg} \mathrm{ml}^{-1}\right)$.

Linkage analysis of glucan. The glucan synthesized was converted into partially methylated alditol acetates and analysed by GLC. The acetate derivatives of 2,3,4,6-tetra-, 2,4,6-tri-, 2,3,4tri- and 2,4-di-O-methyl-D-glucitol were found in the molar ratio of $1 \cdot 0: 0 \cdot 4: 1 \cdot 7: 0 \cdot 4$, indicating that the glucan was composed of $49 \mathrm{~mol} \%$ of $1,6-$ and $11 \mathrm{~mol} \%$ of $1,3-\alpha$-linked glucose with $11 \mathrm{~mol} \%$ of $1,3,6-\alpha$-branch points.

\section{DISCUSSION}

In our preliminary experiments, the attempts to obtain a homogeneous preparation of glucosyltransferase from a culture supernatant of $S$. mutans serotype $b$ (subsp. rattus) always resulted in a low yield of the activity and in multiple forms of the enzyme different in size and charge, as reported by Ciardi et al. (1976). This was probably due to the action of extracellular proteases present during the purification procedures (Grahame \& Mayer, 1984). These problems were largely overcome by the addition, after culture, of PMSF, a serine protease inhibitor (Russell et al., 1983). In the present study, APMSF and $\alpha_{2}$-macroglobulin were added, in addition to PMSF, in order to further inhibit the protease actions after culture and during the purification procedures, and a GT-S was finally obtained in a high state of purity (Figs 1 and 2) from the culture supernatant of $S$. mutans BHT (serotype $b$, subsp. rattus) by DEAE-Sepharose chromatography and preparative IEF, although a trace amount of the other GT-S species, probably derived from the major GT-S species (pI 4.5) by the extracellular proteases, was present in the purified GT-S preparation (Figs 1 and 2).

The GT-S from serotype $b$ was immunologically partially identical with the GT-Ss from serotype $c, e$ and $f$ strains, and immunologically unrelated to the GT-I from serotype $c$ strain and to the GT-S1, GT-S2 and GT-I from serotype $a, d$ and $g$ strains. These results were compatible with those in the inhibition test of enzyme activity by antisera (Smith \& Taubman, 1977) and 
double immunodiffusion tests (Russell, 1979a; Kuramitsu \& Wondrack, 1983), although the GT-S from serotype $c$ was reported to be immunologically unrelated to the crude enzyme preparation from serotype $b$ (Kuramitsu \& Ingersoll, 1976).

The glucan synthesized from sucrose by the GT-S $(b)$ was water-soluble and mostly consisted of 1,6- $\alpha$-linked glucose residues with 1,3- $\alpha$-linked and 1,3,6- $\alpha$-branched glucose residues. This glucan closely resembled the glucans synthesized by GT-S2s purified from serotype $a, d$ and $g$ strains (Shimamura et al., 1983; Koga et al., 1983; Tsumori et al., 1985b) and the glucans by GT-Ss from serotype $c, e$ and $f$ strains (Sato et al., 1984). It may be concluded, therefore, that all the $S$. mutans serotypes secrete enzymes which synthesize soluble glucans mostly consisting of 1,6- $\alpha$-linked glucose residues with lesser amounts of 1,3- $\alpha$-linked and 1,3,6- $\alpha$-branched glucose residues.

Serotype $b$ strains, which are predominantly found in rat oral cavities, may be the most suitable strains for use in studies on preventive dental caries using rats as experimental animals. Therefore, in addition to the GT-S now purified, characterizations of the other glycosyltransferases secreted from serotype $b$ strains, GT-I and fructosyltransferase, would contribute to the elucidation of the caries induction mechanism of $S$. mutans on tooth surfaces.

This work was supported by a grant no. 60771492 from the Japanese Ministry of Education, Science and Culture.

\section{REFERENCES}

CARLSSON, J. (1970). A levansucrase from Streptococcus mutans. Caries Research 4, 97-113.

Ciardi, J. E., Hageage, G. J., JR \& Wittenberger, C. L. (1976). Multicomponent nature of the glucosyltransferase system of Streptococcus mutans. Journal of Dental Research 55, (Special Issue C), C87-C96.

Ciardi, J. E., Beaman, A. J. \& Wittenberger, C. L. (1977). Purification, resolution, and interaction of the glucosyltransferases of Streptococcus mutans 6715. Infection and Immunity 18, 237-246.

Dubois, M. L., Gilles, K. A., Hamilton, J. K., Rebers, P. A. \& SMITH, F. (1956). Colorimetric methods for determination of sugars and related substances. Analytical Chemistry 28, 350-356.

EISENTHAL, R. \& CORNISH-BOWDEN, A. (1974). The direct linear plot. A new graphical procedure for estimating enzyme kinetic parameters. Biochemical Journal 139, 715-720.

Fukui, K., Moriyama, T., Miyake, Y., Mizutani, K. \& TANAKA, O. (1982). Purification and properties of glucosyltransferase responsible for water-insoluble glucan synthesis from Streptococcus mutans. Infection and Immunity 37, 1-9.

Fukushima, K., Motoda, R., Takada, K.\& IKeda, T. (1981). Resolution of Streptococcus mutans glucosyltransferases into two components essential to waterinsoluble glucan synthesis. FEMS Letters 128, 213216.

GibBons, R. J. \& NyGaARD, M. (1968). Synthesis of insoluble dextran and its significance in the formation of gelatinous deposits by plaque-forming streptococci. Archives of Oral Biology 13, 1249-1262.

Grahame, D. A. \& Mayer, R. M. (1984). The origin and composition of multiple forms of dextransucrase from Streptococcus sanguis. Biochimica et biophysica acta 786, 41-48.

HAKOMORI, S. (1964). A rapid permethylation of glycolipid, and polysaccharide catalyzed by methylsulfinyl carbanion in dimethyl sulfoxide. Journal of Biochemistry 55, 205-208.
Koga, T., Sato, S., Yakushij, T. \& Inoue, M. (1983). Separation of insoluble and soluble glucan-synthesizing glucosyltransferases of Streptococcus mutans OMZ176 (serotype d). FEMS Microbiology Letters 16, $127-130$

KuRAMITSU, H. \& INGERSOLL, L. (1976). Immunological relationships between glucosyltransferases from Streptococcus mutans serotypes. Infection and Immunity 14, 636-644.

KuRAMITSU, H. K. \& Wondrack, L. (1983). Insoluble glucan synthesis by Streptococcus mutans serotype $c$ strains. Infection and Immunity 42, 763-770.

MuKasa, H. (1986). Properties of Streptococcus mutans glucosyltransferases. In Molecular Microbiology and Immunobiology of Streptococcus mutans, pp. 121-132. Edited by S. Hamada et al. Amsterdam: Elsevier Science Publishers.

Mukasa, H. \& Slade, H. D. (1973). Mechanism of adherence of Streptococcus mutans to smooth surfaces. I. Roles of insoluble dextran-levan synthetase enzymes and cell wall polysaccharide antigen in plaque formation. Infection and Immunity 8, 555-562.

Mukasa, H. \& SLADE, H. D. (1974). Mechanism of the adherence of Streptococcus mutans to smooth surfaces. III. Purification and properties of the enzyme complex responsible for adherence. Infection and Immunity 10, 1135-1145.

Mukasa, H., Shimamura, A. \& Tsumori, H. (1979). Effect of salts on water-insoluble glucan formation by glucosyltransferase of Streptococcus mutans. Infection and Immunity 23, 564-570.

Mukasa, H., Shimamura, A. \& Tsumori, H. (1982a). Purification and characterization of basic glucosyltransferase from Streptococcus mutans serotype $c$. Biochimica et biophysica acta 719, 81-89.

Mukasa, H., Shimamura, A. \& Tsumori, H. (1982b). Direct activity stains for glycosidase and glucosyltransferase after isoelectric focusing in horizontal polyacrylamide gel layers. Analytical Biochemistry 123, 276-284. 
Mukasa, H., Tsumori, H. \& Shimamura, A. (1985). Isolation and characterization of an extracellular glucosyltransferase synthesizing insoluble glucan from Streptococcus mutans serotype $c$. Infection and Immunity 49, 790-796.

OUCHTERLONY, O. (1958). Diffusion on gel methods for immunological analysis. Progress in Allergy 5, 1-9.

RUSSELL, R. R. B. (1979a). Glycosyltransferases of Streptococcus mutans strain Ingbritt. Microbios 23, 135-146.

Russell, R. R. B. $(1979 b)$. Use of Triton X-100 to overcome the inhibition of fructosyltransferase by SDS. Analytical Biochemistry 97, 173-175.

Russell, R. R. B., Donald, A. C. \& Douglas, C. W. I. (1983). Fructosyltransferase activity of a glucan-binding protein from Streptococcus mutans. Journal of General Microbiology 129, 3243-3250.

SAto, S., Koga, T. \& InOUe, M. (1984). Isolation and some properties of extracellular D-glucosyltransferases and D-fructosyltransferases from Streptococcus mutans serotypes $c, e$ and $f$. Carbohydrate Research 134, 293-304.

SCALES, W. R., Long, L. W. \& EdWARdS, J. R. (1975). Purification and characterization of a glycosyltransferase complex from the culture broth of Streptococcus mutans FA1. Carbohydrate Research 42, 325338.

Shimamura, A., Tsumori, H. \& MUkasa, H. (1982). Purification and properties of Streptococcus mutans extracellular glucosyltransferase. Biochimica et biophysica acta 702, 72-80.

Shimamura, A., Tsumori, H. \& Mukasa, H. (1983). Three kinds of extracellular glucosyltransferases from Streptococcus mutans 6715 (serotype g). FEBS Letters 157, 79-84.

Smith, D. J. \& Taubman, M. A. (1977). Antigenic relatedness of glucosyltransferase enzymes from
Streptococcus mutans. Infection and Immunity 15, 91103.

Somogyi, M. (1945). A new reagent for the determination of sugars. Journal of Biological Chemistry 160 , 61-73.

Terleckyu, B., Willett, N. P. \& Shockman, G. D. (1975). Growth of several cariogenic strains of oral streptococci in a chemically defined medium. Infection and Immunity 11, 649-655.

Tsumori, H., Shimamura, A. \& MUKasa, H. (1983). Comparative study of Streptococcus mutans extracellular glycosyltransferases by isoelectric focusing. Journal of General Microbiology 129, 3261-3269.

TSUmori, H., Shimamura, A. \& MUKasa, H. (1985a). Purification and properties of extracellular glucosyltransferase synthesizing 1,3,- $\alpha$-D-glucan from Streptococcus mutans serotype a. Journal of General Microbiology 131, 553-559.

Tsumori, H., Shimamura, A. \& MUKasa, H. (1985b). Purification and properties of extracellular glucosyltransferase synthesizing 1,6-, 1,3- $\alpha$-D-glucan from Streptococcus mutans serotype $a$. Journal of General Microbiology 131, 3347-3353.

VAN HANDEL, E. (1967). Determination of fructose and fructose-yielding carbohydrates with cold anthrone. Analytical Biochemistry 19, 193-194.

VESTERBERG, O. (1971). Isoelectric focusing of proteins. Methods in Enzymology 22, 389-412.

WEBER, K. \& OSBORN, M. (1969). The reliability of molecular weight determination by dodecyl sulfate polyacrylamide gel electrophoresis. Journal of Biological Chemistry 244, 4406-4412.

Zinner, D. D., Jablon, J. M., ARan, A. P. \& Saslaw, M.S. (1965). Experimental caries induced in animals by streptococci of human origin. Proceedings of the Society for Experimental Biology and Medicine 118, 766-770. 